\title{
Occupational exposure to ultrafine particles in police officers: no evidence for adverse respiratory effects
}

\author{
G. Jordakieva', I. Grabovac ${ }^{2 *}$ (D, E. Valic ${ }^{3}$, K. E. Schmidt ${ }^{4}$, A. Graff', A. Schuster ${ }^{5}$, K. Hoffmann-Sommergruber $^{6}$, \\ C. Oberhuber ${ }^{6}$, O. Scheiner ${ }^{6}$, A. Goll ${ }^{7}$ and J. Godnic-Cvar ${ }^{1}$
}

\begin{abstract}
Background: Inhalation exposure to fine and ultrafine particles (UFPs) has been associated with respiratory diseases. However, little is known on the quality, threshold levels and concentration of these particles causing adverse health effects.

Methods: The impact of occupational exposure to submicrometer and UFPs was assessed in 30 healthy police shooting instructors by clinical investigation, self-assessment questionnaire, sputum and spirometry and compared to a control group. General laboratory chemistry parameters, circulating cytokines (interleukin [LL]-2, IL-4, IL-5, IL-6, IL-8, interferon-gamma [IFN- $\gamma]$ ), and granulocyte macrophage colony-stimulating factor (GM-CSF) in serum were measured. UFP exposure was recorded by Scanning Mobility Particle Sizer.

Results: Concentrations of submicrometer sized airborne particles $(<700 \mathrm{~nm})$ measured between $3.34 \times 10^{5} / \mathrm{cm}^{3}$ and $7.58 \times 10^{5} / \mathrm{cm}^{3}$ at shooting sites, with highest concentrations found in the UFP range $(<100 \mathrm{~nm})$. The size of the monodispersed particles ranged from $54.74 \pm 16.25 \mathrm{~nm}$ to $98.19 \pm 22.83 \mathrm{~nm}$. Short term exposure (4 h) to high levels of UFPs caused an increase of IFN- $\gamma$ in exposed subjects $(p=0.022)$. $24 \mathrm{~h}$ after exposure a significant decrease of IgG, albumin fibrinogen and factor VII was found. Neither directly after $4 \mathrm{~h}$ of high levels UFPs exposure nor $24 \mathrm{~h}$ after exposure subjective complaints or objective measurements indicating adverse respiratory effects in exposed subjects were found.
\end{abstract}

Conclusions: No consistent indications for adverse respiratory or inflammatory effects directly following exposure and $24 \mathrm{~h}$ after exposure to high levels of UFPs in our study group were detected. However we showed the assessment of short-term exposure effects at a genuine occupational setting, which might is relevant when a risk assessment of high level occupational exposures to UFPs is considered.

Keywords: Adverse health effects, Airway obstruction, Inflammation, Occupational exposure, Ultrafine particles, Indoor shooting range

\section{Background}

A relationship between increased ambient air pollution and adverse health effects has been postulated. Exposure to ultrafine particles (UFPs, defined as $<100 \mathrm{~nm}$ [nm] in diameter) has been reported to increase respiratory symptoms, decrease lung function, cause asthma exacerbations,

\footnotetext{
* Correspondence: igor.grabovac@meduniwien.ac.at

${ }^{2}$ Department of Social and Preventive Medicine, Centre for Public Health, Medical University of Vienna, Kinderspitalgasse 15/1, A-1090 Vienna, Austria Full list of author information is available at the end of the article
}

increased medication use and increased hospital admissions related to respiratory diseases [1-7]. UFPs predominantly emerge from industrial (welding and metal smoke, technical carbon-particulate emissions, amorphous silica acid) and traffic emissions. Their adverse health effects have been attributed to high particle number per unit mass and reactive surface [7-13] and associated with airway inflammation with a subsequent release of chemical mediators and cytokines [14-18]. Adjuvant effects have also been observed, e.g. diesel particles have been shown

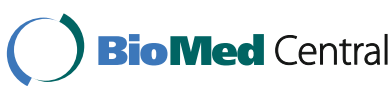

(c) The Author(s). 2018 Open Access This article is distributed under the terms of the Creative Commons Attribution 4.0 International License (http://creativecommons.org/licenses/by/4.0/), which permits unrestricted use, distribution, and reproduction in any medium, provided you give appropriate credit to the original author(s) and the source, provide a link to the Creative Commons license, and indicate if changes were made. The Creative Commons Public Domain Dedication waiver (http://creativecommons.org/publicdomain/zero/1.0/) applies to the data made available in this article, unless otherwise stated. 
to enhance and/or intensify sensitization to common allergens [9, 11, 12, 19-26].

Most of the current knowledge on pathophysiological mechanisms associated with UFPs is derived from cell cultures and animal models. Only a few groups investigated their effects on human subjects [7-10, 12-14, 1621, 23-25, 27, 28].

While acute respiratory effects of exposure to fine particles have been established experimentally and epidemiologically, the contribution of fine particles to the development of chronic disease is less clear [29].

The measurement of UFPs at workplaces in Germany has shown that especially high number concentrations (ranging from a few 1000 to several 100,000 particles/ $\mathrm{cm}^{3}$ ) are associated with combustion processes such as; welding, soldering and metal grinding [30]. Firearm usage generates particulate emissions, which may accumulate in ambient air, particularly in closed spaces such as indoor shooting ranges. Airborne particles originate from explosion and vapour generation during bullet discharge, further releasing metallic components, like lead, barium and antimony. Particle diameters emitted from gunshots were reported to be mostly $<10 \mu \mathrm{m}$ in diameter [31]. Work-site measurements conducted at indoor shooting ranges revealed a clear accumulation of UFPs ranging up to $420,000 / \mathrm{cm}^{3}$ in Swiss and German workplace assessments, depending on exhaust availability [32, 33].

It remains to be established whether exposure to submicrometer and UFPs triggers adverse respiratory effects only in susceptible or in all exposed subjects. Even more so, adverse health effects of UFPs in an occupational setting after several years of exposure have not been evaluated thoroughly.

The aim of this study was to determine whether a defined occupational exposure to UFPs causes adverse health effects in frequently inhalation exposed shooting instructors.

\section{Methods \\ Subjects}

Sixty male subjects $(n=60)$ employed as federal police officers in Vienna, Austria, were included in this study and divided in two groups depending on the level of UFP exposure. The exposed group consisted of 30 police officers working as instructors at a shooting range with an average work history of 4.7 years. The control group comprised 30 police officers working in administration.

\section{Study design}

Measurements in subjects were conducted at a) three time points in the exposed group: time point " 0 exp" $=$ before exposure, time point " 1 exp" = at the day of exposure (after $4 \mathrm{~h}$ of UFP exposure) and time point " 2 exp" $=24 \mathrm{~h}$ after UFP exposure; and at b) two time points in the control group (no occupational UFP exposure) on two separate days (time point " 0 con" and time point " 1 con"). At each of these test points an occupational selfreporting questionnaire was completed and a diagnostic workup performed (spirometry and blood sampling).

\section{Exposure to UFPs and metals}

Shooting ranges have been identified as places with high levels of submicrometer and UFPs [32, 34, 35]. The measurements were conducted at 5 modern police shooting ranges (designated as " $A$ ", "B", “C", "D" and "E"), where UFPs arise from combustion of the explosion in the percussion-cap and metal fumes originating from the metal coat of the bullets (lead, barium, copper and antimony).

The average size of airborne particles (in $\mathrm{nm}$ ), the metal content (in $\mathrm{mg} / \mathrm{m}^{3}$ ) of the inhalable dust and the gaseous pollutants were measured at 5 locations (Table 2). At location A and B the measurements were repeated twice and three times, respectively, on separate days to control for the repeatability of the measured values. The number and size of submicrometer and UFPs under normal working conditions while the ventilation (exhaust) system was operating (air turnover between 22 and 31 air changes/h, air flow from ceiling to target plates) was measured by the stationary Scanning Mobility Particle Sizer (SMPS ${ }^{\mathrm{s}}$, TSI Type 3936 L; Flow Controller Model 120FC TSI; impactor diameter $0,0457 \mathrm{~cm}$ ) and expressed as particles $/ \mathrm{cm}^{3}$ (concentrations indicated as means $+/-\mathrm{SD})$. Measurement range was restricted to particle sizes $15-700 \mathrm{~nm}$ and measured values were presented every $2 \mathrm{~min}$ and $30 \mathrm{~s}$.

Sampling was conducted between 2 and $4 \mathrm{~h}$ (see Table 2) in a total of eight shooting episodes, during which constant target practice was performed by up to 3 persons. The distance between SMPS and shooting person as well as between sampling inlet and pistol outlet were less than a meter, respectively. The study subjects, being shooting instructors, were constantly present at the shooting range and in close proximity to the shooting persons.

All aerosol exposure measurements were performed under normal working conditions with an activated ventilation system. The different particle sizes were determined using a high-voltage area resulting from particle diameter-dependent mobility of the submicrometer and ultrafine aerosol particles in the surrounding gas. First of all the aerosol passes an impactor, which prevents larger particles than those of interest arriving in the system. Subsequently, ionization of the particles takes place using a $\mathrm{Kr}^{87}$ source. In a high-voltage area (DMA 3081 Differential Mobility Analyser) the particles are selected according to their electrical mobility, which is a measure for their size. Mono-dispersive aerosol is supplied to a CPC (Condensation Particle Counter 
3022A), where the particles are brought to the same size with the help of evaporating butanol, in order to be able to count them using a laser. The entirely controlling of the SMPS as well as the data measurement recording was conducted by PC.

Inhalable dust was measured by the personal air sampler (Gilian HFS 513 A Gilian - PAS SG10, GSA building of measure devices $\mathrm{GmbH}$ using a standard kit; Filter type: $10 \mu$ nylon; holder: "O-ring seal"), the high volume sampler Gravikon PM4 (Ströhlein) and the portable dust monitor (Grimm Aerosol Technik GmbH using standard equipment). Personal sampling time was approximately $3 \mathrm{~h}$. Measurements were performed $6 \mathrm{~m}$ and $8 \mathrm{~m}$ away from the shooter and 0 and $2 \mathrm{~m}$ away from the targets; additionally personal sampling was conducted on the shooting instructors themselves. The variability of these measurements was below $6 \%$ (calculated by GRIMM Aerosol Technik GmbH Windows).

Following gaseous pollutants: $\mathrm{CO}, \mathrm{NO}, \mathrm{NO}_{2}$ - were measured by the gas monitor VRAE (RAE Systems). At ranges " $A$ " and " $B$ " the measurements were repeated twice and three times respectively.

To estimate baseline (non-occupational) exposure to UFPs we measured particles with the same methods at a nearby school twice for $16 \mathrm{~h}$ (mainly at nighttime).

\section{Spirometry}

Lung function was assessed by FVC, $\mathrm{FEV}_{1}, \mathrm{MEF}_{50}$ and $\mathrm{MEF}_{25}$ measurements (American Thoracic Society 1995) with a "Flow Screen Pro" spirometer (Jäger, Germany) according to the ATS criteria [36].

\section{Blood sample analysis}

Blood was drawn from periphery veins of participating subjects. After centrifugation (4000 rpm/10 min/room temperature) serum samples were stored at $-20{ }^{\circ} \mathrm{C}$. Two kinds of analyses were performed:

a) Blood cell count (total and differential), biochemical parameters (albumin, C-reactive protein [CRP]), haemostasis parameters (fibrinogen, prothrombin test, coagulation factor VII), immunoglobulins (IgA, $\operatorname{IgG}, \operatorname{IgE}$ ), and lead concentrations in blood were measured in a clinical laboratory.

b) Cytokines (interleukin (IL-)2, IL-4, IL-6, IL-8, interferon (IFN-) $\gamma$, granulocyte macrophage colonystimulating factor (GM-CSF)) were assessed by commercial ELISA (enzyme-linked immunosorbent assay) kits (R\&D Systems, Inc., Minneapolis, USA) according to manufacturer's instructions following the construction of standard curves for each ELISA system. All serum samples were applied in duplicates and undiluted. The tests were performed in an immunological laboratory of the Department of
Pathophysiology and Allergy Research of the Medical University of Vienna.

\section{Statistical methods}

This study was planned as a feasibility study. Descriptive statistics (percentages, means, ranges and standard deviation) were calculated. To investigate the differences in values between the two groups at baseline (before exposure) t-tests, Wilcoxon tests or Chi Square tests were performed as appropriate.

To analyse a possible temporal impact of exposure to submicrometer and UFPs, analyses of covariance was performed for the first measurement after baseline (which is available in exposed and controls) including a fixed grouping factor (exposed/controls) and the baseline value, age and package years as co-variables. A significant grouping factor here indicated a different time course between exposed subjects and controls.

Only within the group of exposed persons, mixed models accounting for time as fixed factor (with three levels) and exposed subjects as a random factor were calculated. No correction for multiple testing was applied in this pilot study. Statistical analyses were performed using SAS Version 9.1.

\section{Results \\ Demographic data}

A total of sixty ( $n=60 ; 100 \%$ male subjects) police officers with $(n=30)$ and without $(n=30)$ occupational UFP exposure were examined. The exposed group consisted of 30 police officers working as instructors at a shooting range with an average work history of 4.7 years. The control group comprised 30 police officers working in administration. Control group subjects were older (41.9 vs. 34.1 years, respectively; $p<0.0001)$ and had a longer (13.17 vs. 6.83 years, respectively; $p=0.020)$ and more intensive (14.47 vs. 5.53 package years, respectively; $p=0.014$ ) smoking history than the exposed subjects (Table 1).

\section{UFPs exposure load}

The size of monodispersed particles ranged from 54,74 $\pm 16,25 \mathrm{~nm}(\mathrm{SD}) \mathrm{nm}$ at location A1 to $98.19 \pm 22.83$ (SD) $\mathrm{nm}$ at location $\mathrm{E}$ (Table 2). The metal content of inhalable dust was on average as follows: lead $0.01 \pm 0.2$ (SD), barium $0.05 \pm 0.04(\mathrm{SD})$, copper $0.01 \pm 0.01(\mathrm{SD})$, and antimony $0.002 \pm 0.01(\mathrm{SD})$. Exposure to gaseous pollutants was neglectable: $\mathrm{CO} 4.86 \pm 4.87$ (SD) ppm, $\mathrm{NO}$ and $\mathrm{NO}_{2}$ expressed as NOx was $<0.1 \mathrm{ppm}$. Baseline (non-occupational) measurements at the control site with the same methods (nearby school) were 0.007 and $0.009 \mathrm{mg} / \mathrm{m}^{3}$ for inhalable dust, whereas the metal content on average was as follows: lead $0.02 \mu \mathrm{g} / \mathrm{m}^{3}$, barium $0.02 \mu \mathrm{g} / \mathrm{m}^{3}$ and copper $0.5 \mu \mathrm{g} / \mathrm{m}^{3}$. 
Table 1 Characteristics of 30 shooting instructors occupationally exposed to UFPs for 4.7 years on average and 30 control participants

\begin{tabular}{|c|c|c|c|}
\hline & Exposed to UFPs & Controls & $\begin{array}{l}p \text {-value } \\
\text { (t-test) }\end{array}$ \\
\hline Age, years (mean) & $34.1 \pm 8.0$ & $41.9 \pm 5.1$ & $<0.0001$ \\
\hline Current smokers \% & 29 & 34 & $0.65^{b}$ \\
\hline Ex-smokers \% & 29 & 31 & $0.87^{\mathrm{b}}$ \\
\hline Years & $\begin{array}{l}6.83 \text { range } \\
(0-25)\end{array}$ & $\begin{array}{l}13.17 \text { range } \\
(0-36)\end{array}$ & $0.02^{\mathrm{a}}$ \\
\hline Pack-years & $\begin{array}{l}5.53 \text { range } \\
(0-30)\end{array}$ & $\begin{array}{l}14.47 \text { range } \\
(0-60)\end{array}$ & $0.01^{\mathrm{a}}$ \\
\hline Body height in $\mathrm{cm}$ & $179.3 \pm 5.5$ & $181.6 \pm 7.3$ & 0.18 \\
\hline Body weight in kg & $80.5 \pm 11.2$ & $84.5 \pm 13.2$ & 0.08 \\
\hline Systolic BP in mmHg & $128.0 \pm 14.1$ & $128.0 \pm 14.9$ & 0.83 \\
\hline Diastolic BP in $\mathrm{mmHg}$ & $82.3 \pm 10.6$ & $82.8 \pm 10.1$ & 0.71 \\
\hline$V C(L)$ & $5.01 \pm 0.93$ & $5.45 \pm 0.97$ & 0.0165 \\
\hline FVC \% & $95.6 \pm 15.6$ & $90.1 \pm 13.4$ & \\
\hline $\mathrm{FEV}_{1} \%$ & $96.8 \pm 13.2$ & $92.8 \pm 17.0$ & \\
\hline $\mathrm{MEF}_{50}(\%)$ & $94.7 \pm 25.7$ & $90.0 \pm 32.0$ & \\
\hline $\mathrm{MEF}_{25}(\%)$ & $85.7 \pm 34.8$ & $72.3 \pm 36.8$ & \\
\hline
\end{tabular}

Data expressed in mean \pm standard deviation

$B P$ blood pressure, $V C$ vital capacity, $F E V_{1}$ forced expiratory volume in one second, $M E F_{50}$ maximum expiratory flow at $50 \%$ of forced $\mathrm{VC}, \mathrm{MEF}_{25}$ maximum expiratory flow at $25 \%$ of forced VC

aWilcoxon test

${ }^{\mathrm{b}}$ ChiSquare test

\section{Self-reported symptoms}

No health complaints, neither local (airways) nor systemic, were reported acutely (after $4 \mathrm{~h}$ of UFP exposure) or belatedly (24 h after exposure). Subjects who were occupationally exposed to submicrometer and UFPs did not report more airway or general health complaints at baseline than subjects in the control group.

Table 2 Exposure to submicrometer sized airborne particles $<700 \mathrm{~nm}$ during 4,5 h of the work shift at 5 different locations

\begin{tabular}{llllll}
\hline Location & $\begin{array}{l}\text { Duration } \\
\text { (in hours) }\end{array}$ & $\begin{array}{l}\text { AM particle } \\
\text { concentration } \\
\left(\mathrm{n} / \mathrm{cm}^{3}\right)\end{array}$ & $\begin{array}{l}\text { Median } \\
\text { particle } \\
\text { size }(\mathrm{nm})\end{array}$ & $\begin{array}{l}\text { Mean } \\
\text { particle } \\
\text { size }(\mathrm{nm})\end{array}$ & $\begin{array}{l}\text { Dominating } \\
\text { Mode }(\mathrm{nm})\end{array}$ \\
\hline A1 & 3.5 & $3.57 \times 10^{5}$ & 54.7 & 67.2 & 56.6 \\
A2 & 3.5 & $5.31 \times 10^{5}$ & 62.3 & 72.8 & 63.3 \\
B1 & 3.5 & $4.66 \times 10^{5}$ & 58.8 & 70.1 & 60.1 \\
B2 & 3.5 & $5.93 \times 10^{5}$ & 60.3 & 70.3 & 64.5 \\
B3 & 4 & $5.39 \times 10^{5}$ & 62.1 & 72.3 & 65.8 \\
C & 3.5 & $4.28 \times 10^{5}$ & 62.8 & 75.4 & 63.4 \\
D & 3.5 & $7.58 \times 10^{5}$ & 78.1 & 89.2 & 83.3 \\
E & 2 & $3.34 \times 10^{5}$ & 98.2 & 109.8 & 101.0 \\
\hline
\end{tabular}

$\mathrm{A}-\mathrm{E}$ : different locations, at location $\mathrm{A}$ and $\mathrm{B}$ the measurements were repeated on 2 and 3 study days, respectively, in parallel to the medical examinations $A M$ arithmetic mean

\section{Spirometry}

- At baseline

Baseline spirometry values significantly differed between the exposed and non-exposed subjects. Baseline vital capacity $(\mathrm{VC})$ values in control subjects were lower than the baseline $\mathrm{VC}$ values in exposed subjects $(5.01 \pm 0.93$ [SD] L vs. $5.45 \pm 0.97[\mathrm{SD}] \mathrm{L}$, respectively, $p=0.0165$ ) as shown in Table 1. In the exposed shooting instructors a significant reduction of the $\mathrm{FEV}_{1}$ lung function parameter (for $0.23 \mathrm{~L}$ on average $p=0.0104$ ) was found only in the $24 \mathrm{~h}$ after exposure spirometry when compared to baseline values. No reduction in $\mathrm{MEF}_{50}$ or in $\mathrm{MEF}_{25}$ was found at any time point (Tables 3 and 4) in exposed subjects. In the control group no significant difference between time point $0^{\text {con }}$ and time point $1^{\text {con }}$ in $\operatorname{FEV}_{1}(p=0.5517), \operatorname{MEF}_{50}(p=0.7302)$ and $\operatorname{MEF}_{25}(p=0.6537)$ was found.

- After $4 \mathrm{~h}$ of UFP exposure and $24 \mathrm{~h}$ after exposure

No significant differences in lung function parameters were found after $4 \mathrm{~h}$ of UFP exposure between exposed and control subjects when adjusted for baseline value, age and package years. Since measurements after $24 \mathrm{~h}$ have only been available for the exposed group we performed a pairwise comparison within the group of exposed subjects. No significant changes were found in lung function parameters, except for the mentioned $\mathrm{FEV}_{1}$ decrease $24 \mathrm{~h}$ after exposure when compared to baseline $\mathrm{FEV}_{1}$.

\section{Blood cell count and serum parameters}

- At baseline

Table 3 Lung function in shooting instructors occupationally exposed to UFPs (3 study points)

\begin{tabular}{llll}
\hline & Timepoint 0 & Timepoint 1 & Timepoint 2 \\
\hline VC (L) & $5.5 \pm 1.0$ & $5.3 \pm 0.9$ & $5.4 \pm 0.7$ \\
VC (\%) & $95.6 \pm 15.5$ & $93.2 \pm 16.2$ & $94.6 \pm 13.5$ \\
$\mathrm{FEV}_{1}(\mathrm{~L})$ & $4.6 \pm 0.7$ & $4.5 \pm 0.7$ & $4.3 \pm 0.6$ \\
$\mathrm{FEV}_{1}(\%)$ & $96.8 \pm 13.2$ & $95.0 \pm 11.2$ & $92.5 \pm 10.5$ \\
$\mathrm{MEF}_{50}(\mathrm{~L} / \mathrm{s})$ & $2.8 \pm 0.8$ & $2.8 \pm 0.8$ & $2.6 \pm 0.7$ \\
$\mathrm{MEF}_{50}(\%)$ & $94.7 \pm 25.7$ & $95.8 \pm 25.7$ & $89.6 \pm 23.0$ \\
$\mathrm{MEF}_{25}(\mathrm{~L} / \mathrm{s})$ & $1.9 \pm 0.3$ & $2.0 \pm 0.2$ & $2.0 \pm 0.2$ \\
$\mathrm{MEF}_{25}(\%)$ & $85.7 \pm 34.8$ & $82.2 \pm 32.9$ & $77.2 \pm 27.2$ \\
\hline
\end{tabular}

Data expressed in mean \pm standard deviation

$\mathrm{VC}$, vital capacity; $\mathrm{FEV}_{1}$, forced expiratory volume in one second; $\mathrm{MEF}_{50}$, maximum expiratory flow at $50 \%$ of forced $\mathrm{VC} ; \mathrm{MEF}_{25}$, maximum expiratory flow at $25 \%$ of forced VC 
Table 4 Lung function of control participants (2 study points)

\begin{tabular}{lll}
\hline & Timepoint 0 & Timepoint 1 \\
\hline VC (L) & $5.0 \pm 0.9$ & $5.1 \pm 0.8$ \\
VC (\%) & $90.1 \pm 13.4$ & $92.6 \pm 12.8$ \\
$\mathrm{FEV}_{1}(\mathrm{~L})$ & $4.2 \pm 0.8$ & $4.1 \pm 0.5$ \\
$\mathrm{FEV}_{1}(\%)$ & $92.8 \pm 17.0$ & $91.15 \pm 10.1$ \\
$\mathrm{MEF}_{50}(\mathrm{~L} / \mathrm{s})$ & $2.4 \pm 0.7$ & $2.4 \pm 0.7$ \\
$\mathrm{MEF}_{50}(\%)$ & $90.0 \pm 11.9$ & $87.1 \pm 29.2$ \\
$\mathrm{MEF}_{25}(\mathrm{~L} / \mathrm{s})$ & $1.7 \pm 0.3$ & $1.7 \pm 0.3$ \\
$\mathrm{MEF}_{25}(\%)$ & $72.3 \pm 36.8$ & $69.2 \pm 26.8$
\end{tabular}

Data expressed in mean \pm standard deviation

$V C$ vital capacity, $F E V_{1}$ forced expiratory volume in one second, $M E F_{50}$ maximum expiratory flow at $50 \%$ of forced $\mathrm{VC}, \mathrm{MEF}_{25}$ maximum expiratory flow at $25 \%$ of forced VC

Exposed subjects had higher albumin values at baseline $(p=0.004)$. Apart from that no significant difference between exposed and control subjects was found in complete and differential blood cell count, biochemical parameters, haemostasis factors, immunoglobulins (IgA, IgG, IgE) and in acute phase proteins (C-reactive protein [CRP] and fibrinogen).

- After $4 \mathrm{~h}$ of UFP exposure and $24 \mathrm{~h}$ after exposure

No difference in measured serum parameters was found after $4 \mathrm{~h}$ of UFP exposure in the exposure group and at the second time point in the control group (see Tables 5 and 6) compared to baseline values. $24 \mathrm{~h}$ after UFP exposure a slight decrease within exposed subjects was observed for albumin (mean difference: 0.96, $p=0.0093$ ), IgG (mean difference 45.3, $p=0.0001$ ), coagulation factor VII (mean difference: $4.87 ; \mathrm{p}=0.009$ ) and fibrinogen (mean difference: $0.8 ; p=0.003$ ) compared to baseline.

\section{Cytokine levels in serum}

- At baseline

Table 5 Biochemical serum parameters in shooting instructors occupationally exposed to UFPs (3 study points)

\begin{tabular}{lllll}
\hline & Timepoint 0 & Timepoint 1 & Timepoint 2 & $p$ value \\
\hline HDL & $51.0 \pm 11.6$ & $49.2 \pm 11.1$ & $50.6 \pm 11.2$ & n.s. \\
LDL & $121.3 \pm 39.8$ & $111.0 \pm 33.9$ & $114.0 \pm 41.4$ & n.s. \\
Cholesterol & $201.3 \pm 46.3$ & $189.4 \pm 44.0$ & $196.2 \pm 44.3$ & n.s. \\
Albumin & $46.8 \pm 2.4$ & $46.5 \pm 3.2$ & $45.8 \pm 2.7$ & 0.0093 \\
lgG & $1066.7 \pm 180.5$ & $1042.0 \pm 183.1$ & $1021.4 \pm 170.7$ & 0.0001 \\
FVII & $101.9 \pm 31.0$ & $99.0 \pm 41.7$ & $97.0 \pm 33.1$ & 0.009 \\
Fibrinogen & $2.5 \pm 0.5$ & $2.1 \pm 0.9$ & $2.0 \pm 0.7$ & 0.003 \\
\hline
\end{tabular}

Data expressed in mean \pm standard deviation

$H D L$ high-density lipoprotein, $L D L$ low-density lipoprotein, IgG immunoglobulin G, FVII factor VII, n.s. non significant
Table 6 Biochemical serum parameters of control participants at 2 study points

\begin{tabular}{llll}
\hline & Timepoint 0 & Timepoint 1 & $p$ value \\
\hline HDL & $50.2 \pm 8.9$ & $53.0 \pm 9.5$ & n.s. \\
LDL & $137.3 \pm 35.0$ & $139.7 \pm 32.5$ & n.s. \\
Cholesterol & $220.0 \pm 38.3$ & $225.5 \pm 38.0$ & n.s. \\
Albumin & $45.1 \pm 1.9$ & $44.8 \pm 1.8$ & n.s. \\
IgG & $1085.1 \pm 203.0$ & $1099.5 \pm 208.4$ & n.s. \\
FVII & $110.5 \pm 20.2$ & $115.0 \pm 18.8$ & n.s. \\
Fibrinogen & $2.6 \pm 0.4$ & $2.7 \pm 0.4$ & n.s. \\
\hline
\end{tabular}

Data expressed in mean \pm standard deviation

$H D L$ high-density lipoprotein, $L D L$ low-density lipoprotein, $\lg G$ immunoglobulin G, FVII factor VII, n.s. non significant

There was no significant difference in cytokine levels in serum (IL-2, IL-4, IL-5, IL-6, IL-8, IFN- $\gamma$ and GMCSF) between exposed subjects and controls at baseline (see Tables 7 and 8).

- After $4 \mathrm{~h}$ of UFP exposure and $24 \mathrm{~h}$ after exposure

No significant changes were found after $4 \mathrm{~h}$ of exposure to UFPs except for a significant increase in IFN- $\gamma$ serum concentration (1.5-fold increase in exposed subjects) ( $p=0.022$, Tables 7 and 8$)$. No significant changes in cytokine levels were found $24 \mathrm{~h}$ after UFP exposure.

\section{Blood metal concentration}

A higher blood lead concentration $(p=0.0008)$ was found in shooting instructors than in controls (109.33 $\pm 103.63(\mathrm{SD}) \mu \mathrm{g} / \mathrm{L}$ vs. $36.24 \pm 20.42 \mu \mathrm{g} / \mathrm{L}$, respectively) at baseline. No significant change in blood lead and other metal concentrations was found following UFP exposure and $24 \mathrm{~h}$ after exposure compared to baseline in the exposed group and at both time points in the control group.

Table 7 Cytokines in sera from shooting instructors occupationally exposed to UFPs $(N=30)$

\begin{tabular}{llll}
\hline Cytokines & Timepoint 0 & Timepoint 1 & Timepoint 2 \\
\hline IL-2 ng/ml & $4.4(0-29.9)$ & $4.0(0-21.8)$ & $5.8(0-51.8)$ \\
IL-4 ng/ml & $0.2(0-3.2)$ & $0.5(0-2.7)$ & $0.1(0-1.0)$ \\
IL-5 ng/ml & $2.2(0-28.6)$ & $2.7(0-26.5)$ & $1.4(0-39.4)$ \\
IL-6 ng/ml & $0.4(0-3.1)$ & $0.9(0-4.3)$ & $0.3(0-1.7)$ \\
IL-8 ng/ml & $16.0(0-73.8)$ & $28.8(0-244.2)$ & $25.7(0-172.6)$ \\
IFN- $-\gamma$ & $9.6(0-87.3)$ & $25.1(0-153.2)$ & $10.7(0-75.1)$ \\
GM-CSF & $0.6(0-4.1)$ & $1.0(0-6.3)$ & $0.8(0-8.4)$ \\
\hline
\end{tabular}

Data expressed in mean (range)

IL interleukin, IFN- $\gamma$ interferon gamma, GM-CSF granulocyte macrophage colony-stimulating factor 
Table 8 Cytokines in sera of control participants $(N=30)$

\begin{tabular}{lll}
\hline Cytokines & Timepoint 0 & Timepoint 1 \\
\hline IL-2 ng/ml & $3.0(0-33.4)$ & $2.6(0-34.5)$ \\
IL-4 ng/ml & $0.02(0-0.7)$ & $0.5(0-13.8)$ \\
IL-5 ng/ml & $7.5(0-101.9)$ & $4.5(0-43.4)$ \\
IL-6 ng/ml & $0.3(0-3.0)$ & $1.3(0-26.3)$ \\
IL-8 ng/ml & $9.6(0-24.0)$ & $14.0(0-87.0)$ \\
IFN- $\gamma$ & $11.5(0-89.1)$ & $10.6(0-53.6)$ \\
GM-CSF & $0.3(0-1.9)$ & $0.2(0-3.4)$ \\
\hline
\end{tabular}

Data expressed in mean (range)

IL interleukin, IFN- $\gamma$ interferon gamma, GM-CSF granulocyte macrophage colony-stimulating factor

\section{Discussion}

Contrary to our expectations, occupational exposure to high doses of submicrometer $(<700 \mathrm{~nm})$ particles, with predominant concentrations in the UFP range, did not cause complaints or significant respiratory effects, neither acutely (after $4 \mathrm{~h}$ hours of exposure) nor belatedly (24 $\mathrm{h}$ after exposure) in our study subjects working as instructors at shooting ranges.

These findings are remarkable because the amount of UFPs at the presented occupational setting (shooting ranges) reached approximately twice the level of episodic peak environmental concentration of UFPs (up to $300,000 / \mathrm{cm}^{3}$ with approximately $50 \mu \mathrm{g} / \mathrm{m}^{3}$ of mass) and belongs to the highest known occupational exposures. UFPs are known to be generally much more biologically aggressive than larger environmental particles, due to their physical properties and their ability to readily cross the alveolo-vascular barrier [23, 37, 38]. The results of our "real life exposure" setting are in concordance with results from controlled laboratory exposures to $500 \mu \mathrm{g} /$ $\mathrm{m}^{3}$ of fine $\left(1.9 \times 10^{5} \mathrm{FP} / \mathrm{cm}^{3}\right.$, median diameter $291.2 \pm$ $20.2 \mathrm{~nm})$ and UF zinc oxide particles $\left(4.6 \times 10^{6}\right.$ UFPs/ $\mathrm{cm}^{3}$, median diameter $40.4 \pm 2.7 \mathrm{~nm}$ ) [39].

A possible explanation for the lack of significant pathological observations after exposure to UFPs could be the characteristics of our examined study population, which were predominantly healthy, young and well trained men. Like in other potentially health-adverse occupational environments, the possibility of a "healthy worker effect" could be considered. According to information obtained from the study subjects themselves, however, ex-collaborators who left this particular working environment rarely did so for health related reasons. In currently available scientific literature, the majority of previously documented harmful effects of UFPs in human subjects were shown in susceptible subjects or in patient groups. Those epidemiologic studies have shown that increased particulate air pollution (PM10 and PM2.5) is significantly associated with increased respiratory and cardiovascular morbidity, worsening of asthma, intensified medication, higher hospital admissions and mortality $[1-3,7]$. Furthermore another study found associations even between ambient UFPs and mortality. Our study group mainly consisted of healthy and physically fit young men, as mentioned above [4].

Although we found a statistically significant late onset impairment (24 h after exposure) of $\mathrm{FEV}_{1}$ air flow, we doubt that it is caused by the exposure to UFPs. Firstly, small airways, which are the target for deposition of fine and ultrafine particles, would be the first to show obstruction in air flow. A matching impairment of $\mathrm{MEF}_{50}$ and $\mathrm{MEF}_{25}$ which reflect the function of the small airways was not found in our subjects. Secondly, $\mathrm{FEV}_{1}$ is, equally to other lung function parameter, influenced by subjects' motivation and effort; thus a decline in readiness for collaboration cannot be excluded at the final measurement. The interpretation of our results is in accordance with several studies [36, 40, 41] who all failed to show a reduction in lung function parameters after exposure to UFPs. Even in asthmatics and patients with chronic pulmonary disease (COPD) no decrease in lung function after exposure to UFPs could be demonstrated [42-44].

Although UFPs readily cross the alveolo-capillary barrier the chosen circulating inflammatory markers (serum cytokine levels and haemostatic factors, as well as biochemical parameters), did not indicate any systemic reaction neither after $4 \mathrm{~h}$ of exposure nor $24 \mathrm{~h}$ after occupational UFP exposure [23, 45, 46], except for an increase in circulating IFN- $\gamma$ levels $4 \mathrm{~h}$ after UFP exposure compared to baseline values. IFN- $\gamma$ is involved in first line innate immune responses to potential pathogens by activation of macrophages [47] and can be released from several cell types, e.g. T cells, natural killer cells and epithelial cells. Immediate increase in IFN- $\gamma$ levels after UFP exposure has not been previously reported in vivo, however, Huang et al. found that ultrafine carbon particle inhalation in healthy individuals induced inflammation related pathways, e.g. T cell receptor and natural killer cell signalling, which might be an associated mechanism for preformed IFN- $\gamma$ release [48]. Notably, a significant decrease of serum albumin, immunoglobulin G (IgG), coagulation factor VII, and fibrinogen was measured $24 \mathrm{~h}$ after UFP exposure. Albumin, IgG and fibrinogen have been shown to bind to ultrafine particles in the bloodstream and are most likely associated with physiological clearance processes [49]. Most available literature showed either no change in IgG levels or a slight increase. These studies were, however, done in sensitized experimental animal models, therefore more research on human participants will be necessary in order to provide a basis for a clinical significance of this finding $[50,51]$. 
A clinical significance of these findings is arguable. In terms of haemostasis, Gilmour et al. [52] previously examined but could not find effects of ultrafine and fine carbon black particle exposure using similar UFP concentrations as measured in our study. Recent data indicates an association between exposure to UFPs (and larger particles) and both, acute-phase proteins and procoagulation parameters, in the same time span considered in our study, which was described as a possible link between air pollution and cardiovascular events [53-56]. Negative correlations between environmental particulate air pollution $\left(\mathrm{PM}_{10}\right)$ and haemoglobin concentration, packed cell volume, red blood count $(p<0.001)$, platelets and factor VII levels $(p<0.05)$, were reported [57] previously, but did not match our results. Data on systemic effects of UFP exposure is in fact controversial in literature, probably depending on the study design, studied population, particle type, model used and questions asked.

The content of lead in blood was significantly higher in the exposed subjects than in the control group (109.33 \pm 103.63 (SD) $\mu \mathrm{g} / \mathrm{L}$ vs. $36.24 \pm 20.42 \mu \mathrm{g} / \mathrm{L} ; p=0.0008$ ), which not only shows that metal particles were indeed incorporated but also that the incorporation exceeded the recommended doses (in Austria maximum blood lead concentrations should be below $90 \mu \mathrm{g} / \mathrm{L}$ in male workers), putting them at higher risk for adverse health effects associated with higher blood lead levels [58].

In occupational settings the concentration and size of UFPs depends not only on the (technological) process, but also on the efficacy of the exhaust system. Efficient exhaust systems predominantly reduce large particle load of the breathing air. Unexpectedly, at two other typical occupational settings with high burdens of UFPs, welding and laser beam application on a glass coating, Riediger and Möhlman [59] have demonstrated that by switching the local exhaust system on, the number of UFPs is reduced for 1 to 1,5 orders of magnitude. In our study, we did not measure the number and size of particles when the exhaust system was turned off because of ethical considerations.

\section{Study limitations}

There are some limitations to our study. Firstly, we initially measured submicrometer sized particles $(<700 \mathrm{~nm})$, but since we did not find adverse respiratory effects and monodispersed particles ranged between $58.85 \pm 16.94$ and $98.19 \pm 22.83 \mathrm{~nm}$ in our measurements, we did not calculate the exact concentrations of UFP $(<100 \mathrm{~nm})$. Secondly, a possible limitation for the lack of adverse effects found in our study could be the absence of reactive metals, since it has been shown before, that oxidative stress induced by UFPs depends on the content of reactive metals. Thirdly, gender differences could not be assessed in this study due to the lack of exposed female subjects, but men may be more resistant to UFPs related adverse health effects than women. Further there were only three time points of air flow measurements: before, $4 \mathrm{~h}$ and $24 \mathrm{~h}$ after exposure. Thus, short-term changes following exposure to UFPs might have been missed. Finally, the young age of our subjects, as well as their overall good health and relatively short continuous exposure to UFPs at the workplace ( 4.7 years on average) might have been limiting study factors.

\section{Conclusions}

We could not detect consistent indications for adverse respiratory or inflammatory effects directly following exposure and $24 \mathrm{~h}$ after exposure to high levels of submicrometer and UFPs in our study group. These findings imply that high levels of submicrometer sized airborne particle concentrations, with a predominant fraction of UFPs, do not induce significant airway inflammation in healthy male subjects. The value of this study is the assessment of the short-term exposure effects to UFPs at a genuine occupational setting, which might is relevant when a risk assessment of high level occupational exposures to UFPs is considered. The implication, furthermore is, that our study supports the theory of a threshold value under which no observed effects level (NOEL) could be found by conventional diagnostic measures in otherwise healthy workers. Longterm prospective studies evaluating the effects of occupational UFPs exposure on human health are however required for the development of reasonable safety measures and preventive work-place related medical surveillance methods.

\section{Acknowledgements}

The authors thank Mr. Karl Mayr and his colleagues from Federal Ministry of Internal Affairs for their contribution and support of this work. We also thank Magdalena Kirnbauer for her valuable technical assistance.

Funding

This study was funded by the Austrian General Insurance Board (AUVA).

\section{Availability of data and materials}

The datasets used and/or analysed during the current study available from the corresponding author on reasonable request.

\section{Authors' contributions}

IG and GJ interpreted the data and wrote the text of the article. EV and JGC wrote the study protocol. KES, AGr, AS, KHS, CO and OS recruited the patients and did the laboratory analyses. AGo did the statystical analysis. All the authors read and agreed on the final version of the manuscript.

Ethics approval and consent to participate

All the subjects gave written informed consent before participating in the study. The research project was approved by the Ethical Committee of the Medical University of Vienna on the 12.01.2004., number EK494/2003.

Consent for publication

Not applicable.

Competing interests

The authors declare that they have no competing interests. 


\section{Publisher's Note}

Springer Nature remains neutral with regard to jurisdictional claims in published maps and institutional affiliations.

\begin{abstract}
Author details
'University Department of Physical Medicine, Rehabilitation and Occupational Medicine, Medical University of Vienna, Waehringer Guertel 18-20, A-1090 Vienna, Austria. ${ }^{2}$ Department of Social and Preventive Medicine, Centre for Public Health, Medical University of Vienna, Kinderspitalgasse 15/1, A-1090 Vienna, Austria. ${ }^{3}$ Austrian Worker's Compensation Board (AUVA), HUB, Adalbert-Stifter-Straße 6, 1200 Vienna, Austria. ${ }^{4}$ University Clinic of Internal Medicine II, Institute of Occupational Medicine, Medical University of Vienna, Waehringer Guertel 18-20, A-1090 Vienna, Austria. ${ }^{5}$ Austrian Dust-Silicosis Control Center (ÖSBS), Einödmayergasse 12, 8700 Leoben, Austria. ${ }^{6}$ Department of Pathophysiology and Allergy Research, Medical University of Vienna, Waehringer Guertel 18-20, A-1090 Vienna, Austria. ${ }^{7}$ Section of Medical Statistics, Core Unit for Medical Statistics and Informatics, Medical University of Vienna, Waehringer Guertel 18-20, A-1090 Vienna, Austria.
\end{abstract}

Received: 9 March 2017 Accepted: 25 January 2018

Published online: 03 February 2018

\section{References}

1. Dockery DW, Schwartz J, Spengler JD. Air pollution and daily mortality: associations with particulates and acid aerosols. Environ Res. 1992;59:362-73.

2. Dockery DW, Pope CA 3rd, Xu X, et al. An association between air pollution and mortality in six U.S. cities. N Engl J Med. 1993;329:1753-9.

3. Dockery DW. Epidemiologic evidence of cardiovascular effects of particulate air pollution. Environ Health Perspect. 2001;109(Suppl 4):483-6.

4. Ibald-Mulli A, Wichmann HE, Kreyling W, Peters A. Epidemiological evidence on health effects of ultrafine particles. J Aerosol Med. 2002;15:189-201.

5. Buonanno G, Marks GB, Morawska L. Health effects of daily airborne particle dose in children: direct association between personal dose and respiratory health effects. Environ Pollut. 2013;180:246-50.

6. Pope CA 3rd, Dockery DW. Health effects of fine particulate air pollution: lines that connect. J Air Waste Manag Assoc. 2006;56:709-42.

7. Donaldson K, Stone V, Clouter A, Renwick L, MacNee W. Ultrafine particles. Occup Environ Med. 2001;58:211-6. 199.

8. Utell MJ, Frampton MW. Acute health effects of ambient air pollution: the ultrafine particle hypothesis. J Aerosol Med. 2000;13:355-9.

9. Donaldson $K$, Tran L, Jimenez LA, et al. Combustion-derived nanoparticles: a review of their toxicology following inhalation exposure. Part Fibre Toxicol. 2005;2:10.

10. MacNee W, Donaldson K. Mechanism of lung injury caused by PM10 and ultrafine particles with special reference to COPD. Eur Respir J Suppl. 2003; 40:47s-51s.

11. Oberdorster G, Oberdorster E, Oberdorster J. Nanotoxicology: an emerging discipline evolving from studies of ultrafine particles. Environ Health Perspect. 2005;113:823-39.

12. Borm PJ, Robbins D, Haubold S, et al. The potential risks of nanomaterials: a review carried out for ECETOC. Part Fibre Toxicol. 2006;3:11

13. Oberdorster G. Pulmonary effects of inhaled ultrafine particles. Int Arch Occup Environ Health. 2001;74:1-8.

14. Salvi SS, Nordenhall C, Blomberg A, et al. Acute exposure to diesel exhaust increases IL-8 and GRO-alpha production in healthy human airways. Am J Respir Crit Care Med. 2000;161:550-7.

15. Totlandsdal Al, Cassee FR, Schwarze P, Refsnes M, Lag M. Diesel exhaust particles induce CYP1A1 and pro-inflammatory responses via differential pathways in human bronchial epithelial cells. Part Fibre Toxicol. 2010;7:41.

16. Donaldson K, Brown D, Clouter A, et al. The pulmonary toxicology of ultrafine particles. J Aerosol Med. 2002;15:213-20.

17. Reibman J, Hsu Y, Chen LC, et al. Size fractions of ambient particulate matter induce granulocyte macrophage colony-stimulating factor in human bronchial epithelial cells by mitogen-activated protein kinase pathways. Am J Respir Cell Mol Biol. 2002;27:455-62.

18. Hohr D, Steinfartz Y, Schins RP, et al. The surface area rather than the surface coating determines the acute inflammatory response after instillation of fine and ultrafine $\mathrm{TiO}_{2}$ in the rat. Int J Hyg Environ Health. 2002;205:239-44.
19. Riedl M, Diaz-Sanchez D. Biology of diesel exhaust effects on respiratory function. J Allergy Clin Immunol. 2005;115:221-8. quiz 9.

20. Diaz-Sanchez D, Tsien A, Fleming J, Saxon A. Combined diesel exhaust particulate and ragweed allergen challenge markedly enhances human in vivo nasal ragweed-specific IgE and skews cytokine production to a T helper cell 2-type pattern. J Immunol. 1997;158:2406-13.

21. Diaz-Sanchez D, Tsien A, Casillas A, Dotson AR, Saxon A. Enhanced nasal cytokine production in human beings after in vivo challenge with diesel exhaust particles. J Allergy Clin Immunol. 1996;98:114-23.

22. Jantzen K, Roursgaard M, Desler C, Loft S, Rasmussen L, Moller P. Oxidative damage to DNA by diesel exhaust particle exposure in co-cultures of human lung epithelial cells and macrophages. Mutagenesis. 2012;27:693-701.

23. Nemmar A, Hoet PH, Vanquickenborne B, et al. Passage of inhaled particles into the blood circulation in humans. Circulation. 2002;105:411-4.

24. Frampton MW. Systemic and cardiovascular effects of airway injury and inflammation: ultrafine particle exposure in humans. Environ Health Perspect. 2001;109(Suppl 4):529-32.

25. Oberdorster $\mathrm{G}$, Utell MJ. Ultrafine particles in the urban air: to the respiratory tract-and beyond? Environ Health Perspect. 2002;110:A440-1.

26. Stewart JC, Chalupa DC, Devlin RB, et al. Vascular effects of ultrafine particles in persons with type 2 diabetes. Environ Health Perspect. 2010;118:1692-8.

27. Vattanasit $U$, Navasumrit $P$, Khadka MB, et al. Oxidative DNA damage and inflammatory responses in cultured human cells and in humans exposed to traffic-related particles. Int J Hyg Environ Health. 2014;217:23-33.

28. Nemmar A, Hoylaerts MF, Hoet PH, et al. Ultrafine particles affect experimental thrombosis in an in vivo hamster model. Am J Respir Crit Care Med. 2002;166:998-1004

29. Mills NL, Donaldson K, Hadoke PW, et al. Adverse cardiovascular effects of air pollution. Nat Clin Pract Cardiovasc Med. 2009;6:36-44.

30. Wurster U. Nanomaterialien: Arbeitsschutzpakete. In: LUBW Landesanstalt für Umwelt MuNB-W, ed. wwwlubwbadem-wuertembergde. Postfach 1001 63, 76231 Karlsruhe: LUBW Landesanstalt für Umwelt, Messungen und Naturschutz Baden-Württemberg; 2009.

31. Melo G, Martiny A, Pinto AL. Nano characterization of gunshot residues from Brazilian ammunition. Forensic Sci Int. 2014;240:69-79.

32. Airports Council International. Ultrafine Particles at Airports. Discussion and Assessment of Ultrafine Particles (UFP) in Aviation and ant Airports in 2012. Available at: https://www.cph.dk/contentassets/04a9b35237a547d1a924ea3c 9df25c31/aci-europe-study-on-ultrafine-particles-at-airports.pdf. Accessed 11 Sept 2017.

33. Landesanstalt für Umwelt, Messungen und Naturschutz BadenWürttemberg. Umweltforschung Journal 2006. Available at: https://www4. lubw.baden-wuerttemberg.de/servlet/is/19970/umweltforschung_journal_ 2006.pdf?command=downloadContent\&filename=umweltforschung_ journal_2006.pdf. Accessed 10 Sept 2017.

34. Viana $\bar{M}$, Fonseca AS, Alastuey A, Querol X, Rodriguez A. Exposure to nanoparticle emissions inside firing ranges. Available at: http://www.isiaq.or g/docs/Papers/Paper427.pdf. Accessed 10 Sept 2017

35. Campagna M, Marcias G, Angius N, et al. 0277 Environmental exposure to nanoparticles in Sardinia, Italy: a pilot study of residential exposure nearby an industrial area and a military shooting range. Occup Environ Med. 2014;71:A99.

36. Quanjer PH, Tammeling GJ, Cotes JE, Pedersen OF, Peslin R, Yernault JC. Lung volumes and forced ventilatory flows. Report working party standardization of lung function tests, European Community for steel and coal. Official statement of the European Respiratory Society. Eur Respir J Suppl. 1993;16:5-40.

37. Brown DM, Wilson MR, MacNee W, Stone V, Donaldson K. Size-dependent proinflammatory effects of ultrafine polystyrene particles: a role for surface area and oxidative stress in the enhanced activity of ultrafines. Toxicol Appl Pharmacol. 2001;175:191-9.

38. Li N, Sioutas C, Cho A, et al. Ultrafine particulate pollutants induce oxidative stress and mitochondrial damage. Environ Health Perspect. 2003;111:455-60.

39. Beckett WS, Chalupa DF, Pauly-Brown A, et al. Comparing inhaled ultrafine versus fine zinc oxide particles in healthy adults: a human inhalation study. Am J Respir Crit Care Med. 2005;171:1129-35.

40. Oberdorster G, Gelein RM, Ferin J, Weiss B. Association of particulate air pollution and acute mortality: involvement of ultrafine particles? Inhal Toxicol. 1995;7:111-24.

41. Li XY, Brown D, Smith S, MacNee W, Donaldson K. Short-term inflammatory responses following intratracheal instillation of fine and ultrafine carbon black in rats. Inhal Toxicol. 1999;11:709-31. 
42. Gong H Jr, Sioutas C, Linn WS. Controlled exposures of healthy and asthmatic volunteers to concentrated ambient particles in metropolitan Los Angeles. Res Rep Health Eff Inst. 2003;(118):1-36. discussion 37-47.

43. Frampton MW, Utell MJ, Zareba W, et al. Effects of exposure to ultrafine carbon particles in healthy subjects and subjects with asthma. Res Rep Health Eff Inst. 2004;(126):1-47. discussion 49-63.

44. de Hartog JJ, Ayres JG, Karakatsani A, et al. Lung function and indicators of exposure to indoor and outdoor particulate matter among asthma and COPD patients. Occup Environ Med. 2010;67:2-10.

45. Geiser M, Kreyling WG. Deposition and biokinetics of inhaled nanoparticles. Part Fibre Toxicol. 2010;7:2

46. Elder A, Oberdorster G. Translocation and effects of ultrafine particles outside of the lung. Clin Occup Environ Med. 2006;5:785-96.

47. Schroder K, Hertzog PJ, Ravasi T, Hume DA. Interferon-y: an overview of signals, mechanisms and functions. J Leukoc Biol. 2003;75(2):163-89.

48. Beck-Speier I, Karg E, Behrendt H, Stoeger T, Alessandrini F. Ultrafine particles affect the balance of endogenous pro- and anti-inflammatory lipid mediators in the lung: in-vitro and in-vivo studies. Part Fibre Toxicol. 2012 Jul 18;9:27.

49. Aggarwal P, Hall JB, McLeland CB, Dobrovolskaia MA, McNeil SE. Nanoparticle interaction with plasma proteins as it relates to particle biodistribution, biocompatibility and therapeutic efficacy. Adv Drug Deliv Re. 2009:61(6):428-37.

50. Barrett EG, Rudolph K, Bowen LE, Muggenburg BA, Bice DE. Effect of inhaled ultrafine carbon particles on the allergic airway response in ragweedsensitized dogs. Inhal Toxicol. 2003;15:151-65.

51. Kleinman MT, Hamade A, Meacher D, et al. Inhalation of concentrated ambient particulate matter near a heavily trafficked road stimulates antigen-induced airway responses in mice. J Air Waste Manag Assoc. 2005;55:1277-88.

52. Gilmour PS, Ziesenis A, Morrison ER, et al. Pulmonary and systemic effects of short-term inhalation exposure to ultrafine carbon black particles. Toxicol Appl Pharmacol. 2004;195:35-44.

53. Ruckerl $\mathrm{R}$, Greven $\mathrm{S}$, Ljungman $\mathrm{P}$, et al. Air pollution and inflammation (interleukin-6, C-reactive protein, fibrinogen) in myocardial infarction survivors. Environ Health Perspect. 2007;115:1072-80

54. Tsai DH, Amyai N, Marques-Vidal P, et al. Effects of particulate matter on inflammatory markers in the general adult population. Part Fibre Toxicol. 2012;9:24.

55. Miller KA, Siscovick DS, Sheppard L, et al. Long-term exposure to air pollution and incidence of cardiovascular events in women. N Engl J Med. 2007;356:447-58.

56. Ruckerl R, Phipps RP, Schneider A, et al. Ultrafine particles and platelet activation in patients with coronary heart disease-results from a prospective panel study. Part Fibre Toxicol. 2007;4:1.

57. Seaton A, MacNee W, Donaldson K, Godden D. Particulate air pollution and acute health effects. Lancet. 1995;345:176-8.

58. Wilhelm M, Heinzow B, Angerer J, Schulz C. Reassessment of critical lead effects by the German human biomonitoring commission results in suspension of the human biomonitoring values (HBM I and HBM II) for lead in blood of children and adults. Int J Hyg Environ Health. 2010;213:265-9.

59. Riediger G, Möhlmann C. Ultrafeine Aerosole an Arbeitsplätzen. Konventionen und Beispiele aus der Praxis Gefahrenstoffe Reinhalt Luft. 2001;61:42.

\section{Submit your next manuscript to BioMed Central and we will help you at every step:}

- We accept pre-submission inquiries

- Our selector tool helps you to find the most relevant journal

- We provide round the clock customer support

- Convenient online submission

- Thorough peer review

- Inclusion in PubMed and all major indexing services

- Maximum visibility for your research

Submit your manuscript at www.biomedcentral.com/submit

) Biomed Central 